\title{
Development of stability indicating method for the simultaneous estimation of alogliptin and pioglitazone in bulk and tablet dosage form by reversed-phase ultra-performance liquid chromatography method
}

\author{
Ramesh Dhani ${ }^{1 *}$, Harish Kumar Donthi Ramachandra Guptha², Deveswaran Rajamanickam ${ }^{3}$ \\ ${ }^{1}$ Research Scholar, Faculty of Pharmacy, M. S. Ramaiah University of Applied Sciences, Bangalore, India. \\ ${ }^{2}$ Department of Pharmaceutical Chemistry, Faculty of Pharmacy, M. S. Ramaiah University of Applied Sciences, Bangalore, India. \\ ${ }^{3}$ Department of Pharmaceutics, Faculty of Pharmacy, M. S. Ramaiah University of Applied Sciences, Bangalore, India.
}

\begin{tabular}{l}
\hline ARTICLE INFO \\
\hline Received on: 14/05/2019 \\
Accepted on: 09/09/2019 \\
Available online: 03/12/2019 \\
\hline Key words: \\
Alogliptin, pioglitazone, BEH \\
C $_{18}$, RP-UPLC, phosphate \\
buffer.
\end{tabular}

\begin{abstract}
The objective of the work is to develop and validate a new reverse phased ultra-performance chromatography method and its stability studies for the simultaneous estimation of alogliptin and pioglitazone in bulk and tablet dosage form. The column of the method was BEH C18 $(2.1 \times 50 \mathrm{~mm}, 1.7 \mu)$ used as a stationary phase and the mobile phase was $45: 55 \mathrm{v} / \mathrm{v}$ of phosphate buffer $(\mathrm{pH} 3)$ and methanol, respectively. The injection volume was $2 \mu \mathrm{l}$ and flow rate was maintained at $0.3 \mathrm{ml} /$ minute. The wavelength was $280 \mathrm{~nm}$ and the runtime was 3 minutes. The retention time of alogliptin was 0.4 minutes and pioglitazone was 0.529 minutes. The Linearity of the alogliptin was $6.25-37.5 \mu \mathrm{g} / \mathrm{ml}$ and pioglitazone was $15-90 \mu \mathrm{g} / \mathrm{ml}$. The newly developed method could be used for the routine analysis of pure drug and its formulations in accordance with the ICH Q2 (R1) guidelines.
\end{abstract}

\section{INTRODUCTION}

Alogliptin (Fig. 1) decreases the incretin glucose dependent insulinotropic polypeptide (GIP) and glucagon like peptide (GLP-2) (Cabrera et al., 2013) increases the plasma incretin concentration, which can controls the glucose levels in the blood (Marino and Cole, 2015). GIP and GLP-2 are stimulating the glucose dependent pancreatic beta cells. It inhibits the activity of GIP and GLP-2 (Cyrus and Vijay, 2010).

Pioglitazone (Fig. 2) is a thiazolidine class of antidiabetic drug (Brunetti et al., 2010). It is an agonist of peroxisome proliferator activated receptor gamma and it activates the insulin

"Corresponding Author

Ramesh Dhani, Research Scholar, Faculty of Pharmacy, M. S. Ramaiah University of Applied Sciences, Bangalore, India.

E-mail:dhaniramesh1@gmail.com responsive genes then increase the production insulin (Al-Majed et al., 2016; Lincoff et al., 2007).

On extensive survey of literature, very few reverse phased high-performance chromatography (RP-HPLC) methods have been reported for the estimation of alogliptin and pioglitazone combined dosage form (Vasanthi et al., 2017). The present developed reversed-phase ultra-performance liquid chromatography (RP-UPLC) method was accurate, precise, and robust for the simultaneous estimation of alogliptin and pioglitazone in Active Pharmaceutical Ingredient and tablet dosage form. The developed RP-UPLC method showed better resolution and low retention time, very good separation efficiency, and faster elution and tiny amount of sample consumed when compared to the (Vasanthi et al., 2017) reported RP-HPLC methods.

\section{MATERIALS AND METHODS}

\section{Instruments used}

The liquid chromatographic system was made up of Waters-Acquity, Japan, UPLC equipped with auto sampler and 
<smiles>Cn1c(N2CCCC(N)C2)cc(=O)n(Cc2ccccc2C#N)c1=O</smiles>

Figure 1. Structure of alogliptin.

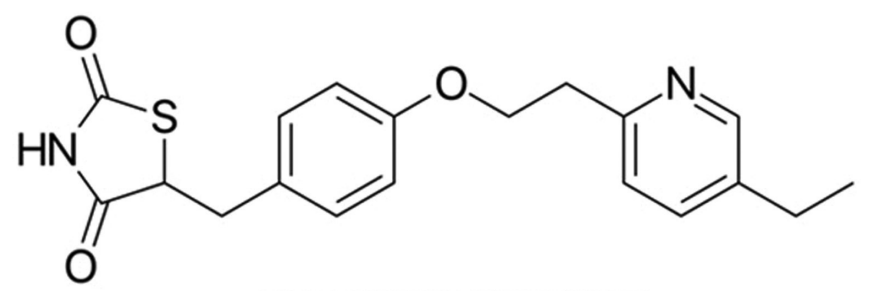

Figure 2. Structure of pioglitazone.

2996 PDA detector with Empower 2 software. Chromatographic separation was performed on waters $\mathrm{BEH} \mathrm{C}_{18}(2.1 \times 50 \mathrm{~mm}, 1.7 \mu)$ column.

\section{Chemicals used}

Gift samples of alogliptin and pioglitazone are procured from Pharma Train, Hyderabad, India. HPLC grade water and methanol are purchased from Merck Laboratories, Mumbai, India. Potassium dihydrogen phosphate $\left(\mathrm{K}_{2} \mathrm{H}_{2} \mathrm{PO}_{4}\right)$ was obtained from Finar Chemicals Pvt. Limited, Ahmedabad, Gujarat, India.

\section{Chromatographic conditions}

Column : Waters BEHC $\mathrm{BE}_{18}(2.1 \mathrm{~mm} * 50 \mathrm{~mm}, 1.7 \mu)$

Mobile phase ratio: Phosphate buffer ( $\mathrm{pH}$ 3):Methanol (45:55)

Wavelength $: 280 \mathrm{~nm}$

Flow rate $\quad: 0.3 \mathrm{ml} / \mathrm{minute}$

Injection volume : $2 \mu 1$

Run time : 3 minute

\section{Preparation of mobile phase}

$450 \mathrm{ml}(45 \%)$ of phosphate Buffer and $550 \mathrm{ml}(55 \%)$ of Methanol was taken and ultra sonicated for 10-15 minutes for degassing, further filtered. $\mathrm{pH}$ was adjusted to 3 with orthophosphoric acid (Raval and Srinivasa, 2014).

\section{Preparation of standard}

$12.5 \mathrm{mg}$ of alogliptin and $30 \mathrm{mg}$ of pioglitazone was taken in 100-ml volumetric flask then $70 \mathrm{ml}$ of diluent was added and dissolved completely, the volume was made up to the mark (Stock solution). $1.5 \mathrm{ml}$ of stock solution was pipette out into $10 \mathrm{ml}$ volumetric flask and the volume was made up to the mark with diluent (Neelima et al., 2014).

\section{Validation of analytical method}

The developed RP-UPLC method was validated for System suitability, Specificity, Linearity, Accuracy, Precision, Robustness, and stability studies. The validation in accordance with ICH guidelines $\mathrm{Q}_{2}\left(\mathrm{R}_{1}\right)$.

\section{System suitability}

It was performed before each validation to check the retention time, theoretical plates, tailing factor, and resolution determined to five suitability injections (Manzoor et al., 2015).

\section{Specificity}

It was carried out to determine the analyte in the presence of other compounds, such as impurities, degradants, and matrix. In specificity study standard injection was compared to the running blank injection.

\section{Linearity}

From the standard stock solution, appropriate aliquots of alogliptin and pioglitazone were taken in different volumetric flask and make up the volume up to the mark with diluent to obtain different concentrations are $6.25,12.5,18.75,25,31.25$, and $37.5 \mu \mathrm{g} / \mathrm{ml}$ for alogliptin and $15,30,45,60,75$, and $90 \mu \mathrm{g} / \mathrm{ml}$ for pioglitazone, respectively (Haribabu et al., 2017). The solutions are injected into $2 \mu \mathrm{l}$ fixed loop system and then chromatograms were recorded. The calibration curve was plotted by concentration Vs Peak area.

\section{Precision}

Both intraday and inter day was carried out for six injections in the day and between the days.

\section{Accuracy}

Recovery was obtained by adding known quantities of pure standard in three different concentrations $50 \%, 100 \%$, and $150 \%$ to the pre-analyzed sample formulation. The amount of drug found, amount of drug recovered, and percentage recovery were calculated for the confirmation of the method accuracy (Komal and Amrita, 2015).

\section{Robustness}

It is an analytical procedure to measure the capacity to remain unaffected by small variations in the method parameter. Some typical variations impacts on method were flow rate, temperature, $\mathrm{pH}$ of mobile phase, and mobile phase composition.

As part of the Robustness, deliberate change in the Flow rate, Mobile Phase composition, Temperature Variation were made to evaluate the impact on the method. From the Standard solution, $18.75 \mathrm{ppm}$ of alogliptin and $45 \mathrm{ppm}$ of pioglitazone was prepared and analyzed using the varied flow rate and wave length change along with actual conditions.

\section{Forced degradation studies}

$1.5 \mathrm{ml}$ from the stock solution was taken in 5 different $10 \mathrm{ml}$ volumetric flasks. The required aliquots are prepared and the solutions are exposed to the stress conditions, such as acidic, 
alkaline, peroxide, thermal, and photolytic conditions (Mokhtar et al., 2016). Then, finally the amount of drug degraded in stress conditions was calculated. The data were shown in Table 10.

\section{RESULTS AND DISCUSSION}

\section{System suitability}

The retention time of alogliptin was 0.403 minutes and pioglitazone was 0.529 minutes. Three system suitability injections were injected into the chromatographic column. Then, the tailing factor, theoretical plates and resolution was calculated. The results are shown in Table 1 and the values were found to be within the limit.

\section{Specificity}

Comparing the results of standard solution along with running blank solution, there was no interference in blank.

\section{Linearity}

For the determining the linearity, plot the graph peak versus concentration and calculate the correlation coefficient. The correlation coefficient and regression equation of alogliptin (Fig. 4) was found to be $Y=797.9 x-228.7\left(r^{2}=0.9997\right)$ and pioglitazone (Fig. 5) was found to be $Y=2157.4 x-40.1$ $\left(r^{2}=0.9998\right)$. The results are shown in Table 2 and Figure 3.

\section{Accuracy}

The mean percentage recovery of alogliptin was $100.34 \%$ and pioglitazone was $100.30 \%$. It was present within the limit, hence the method was accurate and it is shown in Tables 3 and 4.

\section{Precision}

It was carried out in intraday and intermediate day for the \% Relative Standard Deviation (RSD) calculation. The results

Table 1. System suitability parameters for alogliptin and pioglitazone.

\begin{tabular}{clccccc}
\hline S. no & Peak name & RT & Area & Height & USP tailing & USP plate count \\
\hline 1 & Alogliptin & 0.403 & 14,601 & 2,825 & 1.16 & 3,083 \\
2 & Alogliptin & 0.412 & 14,715 & 2,847 & 1.13 & $3,479.74$ \\
3 & Alogliptin & 0.415 & 14,585 & 2,822 & 1.13 & $3,260.44$ \\
4 & Pioglitazone & 0.529 & 96,100 & 15,802 & 1.31 & $3,760.10$ \\
5 & Pioglitazone & 0.535 & 97,019 & 15,953 & 1.37 & $3,205.44$ \\
6 & Pioglitazone & 0.541 & 95,651 & 15,728 & 1.33 & $3,815.62$ \\
\hline
\end{tabular}

Table 2. Linearity results.

\begin{tabular}{cccccc}
\hline \multirow{2}{*}{ S. no } & $\begin{array}{c}\text { Linearity } \\
\text { level }\end{array}$ & \multicolumn{2}{c}{ Alogliptin } & \multicolumn{2}{c}{ Pioglitazone } \\
\cline { 3 - 6 } & Concentration & Area & Concentration & Area \\
\hline 1 & I & 6.25 & 14,8485 & 15 & 32,573 \\
2 & II & 12.5 & 159,870 & 30 & 64,978 \\
3 & III & 18.75 & 172,969 & 45 & 96,453 \\
4 & IV & 25 & 185,137 & 60 & 128,673 \\
5 & V & 31.25 & 196,786 & 75 & 162,527 \\
6 & VI & 37.5 & 208,365 & 90 & 195,462 \\
\hline
\end{tabular}

were found to be under accepted criteria, i.e., $2 \%$. It is shown in Tables 5 and 6.

\section{LOD and LOQ}

The Limit of Detection (LOD) of alogaliptin and pioglitazone found to be 2.91 and $2.96 \mu \mathrm{g} / \mathrm{ml}$. The Limit of Quantification (LOQ) of alogliptin was 10.4 and $10.09 \mu \mathrm{g} / \mathrm{ml}$ for pioglitazone, respectively. The results are shown in Table 7.

\section{Robustness}

The variation of flow rate and wavelength was found to be $(+10 \%)$, which was affected by the method. The standard solutions were injected under the selected robust conditions. The system suitability parameters, such as theoretical plates, tailing factor and resolution was observed and measured. Results shows $>2000$ theoretical plate count, $<2$ of tailing factor and resolution was found to be $>2$ (See Tables 8 and 9). Hence the method was robust and the results were shown in Figures 6 to 9.

\section{Forced degradation studies}

The working standards of alogliptin and pioglitazone were placed in different stress conditions, such as acid, base, thermal, peroxide, and photolytic conditions, and then observe the amount of drug degraded in above stress conditions. The results of degradation study of standard solutions were stable in all the selected stress conditions and there is no observe the much deviation. The results obtained were compared with existing methods and found to be stable in all stress conditions, but existing

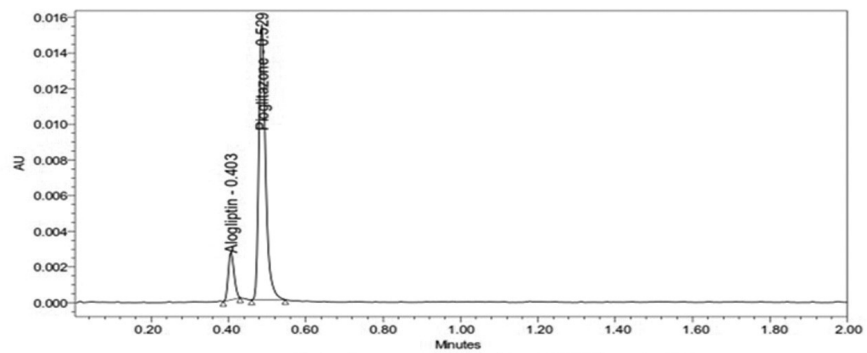

Figure 3. Optimized chromatogram for alogliptin and pioglitazone.

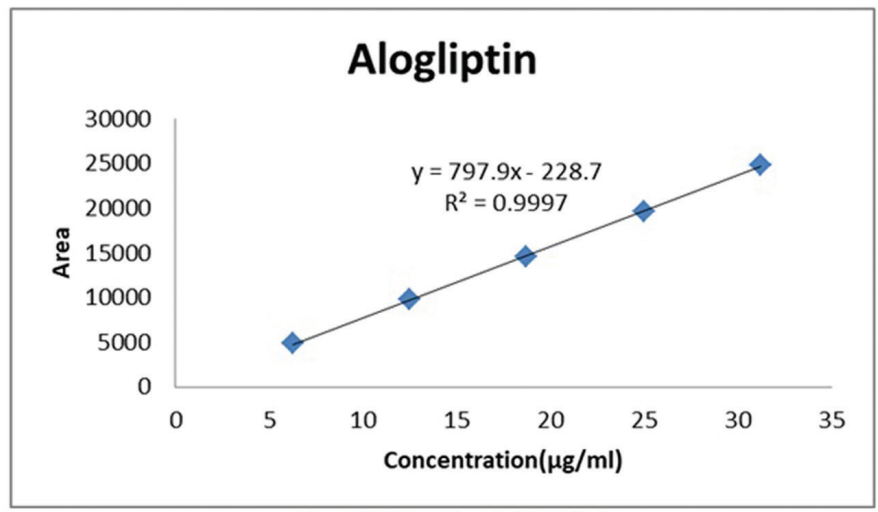

Figure 4. Linearity graph of alogliptin. 
Table 3. The accuracy results for alogliptin.

\begin{tabular}{cccccc}
\hline $\begin{array}{c}\text { \%Concentration } \\
\text { (at specification Level) }\end{array}$ & Area & $\begin{array}{c}\text { Amount } \\
\text { added (mg) }\end{array}$ & $\begin{array}{c}\text { Amount } \\
\text { found (mg) }\end{array}$ & \% Recovery & $\begin{array}{c}\text { Mean } \\
\text { recovery }\end{array}$ \\
\hline $50 \%$ & 7,352 & 6.25 & 6.27 & 100.28 & \\
$100 \%$ & 14,665 & 12.5 & 12.50 & 100.04 & $100.34 \%$ \\
$150 \%$ & 22,155 & 18.75 & 18.89 & 100.73 & \\
\hline
\end{tabular}

Table 4. The accuracy results for pioglitazone.

\begin{tabular}{cccccc}
\hline $\begin{array}{c}\text { \%Concentration } \\
\text { (at specification Level) }\end{array}$ & Area & $\begin{array}{c}\text { Amount } \\
\text { added (mg) }\end{array}$ & $\begin{array}{c}\text { Amount } \\
\text { found (mg) }\end{array}$ & \% Recovery & $\begin{array}{c}\text { Mean } \\
\text { recovery }\end{array}$ \\
\hline $50 \%$ & 48,228 & 15 & 15.00 & 100.01 & \\
$100 \%$ & 96,846 & 30 & 30.12 & 100.41 & $100.30 \%$ \\
$150 \%$ & $327,988.3$ & 45 & 45.22 & 100.47 & \\
\hline
\end{tabular}

Table 5. Results for intraday precision.

\begin{tabular}{ccc}
\hline Injection & Area for alogliptin & Area for pioglitazone \\
\hline Injection-1 & 14,572 & 96,756 \\
Injection-2 & 14,497 & 96,245 \\
Injection-3 & 14,756 & 96,786 \\
Injection-4 & 14,678 & 96,458 \\
Injection-5 & 14,565 & 96,452 \\
Injection-6 & 14,767 & 96,753 \\
Average & $14,639.2$ & $96,575.0$ \\
Standard Deviation & 111.1 & 222.1 \\
\%RSD & 0.8 & 0.2 \\
\hline
\end{tabular}

Table 6. Results for intermediate precision.

\begin{tabular}{ccc}
\hline Injection & Area for alogliptin & Area for pioglitazone \\
\hline Injection-1 & 14,872 & 96,836 \\
Injection-2 & 14,756 & 96,486 \\
Injection-3 & 14,582 & 96,435 \\
Injection-4 & 14,643 & 96,856 \\
Injection-5 & 14,869 & 96,456 \\
Injection-6 & 14,668 & 96,786 \\
Average & $14,731.7$ & $96,642.5$ \\
Standard Deviation & 121.2 & 203.0 \\
\%RSD & 0.8 & 0.2 \\
\hline
\end{tabular}

Table 7. Results for LOD and LOQ.

\begin{tabular}{ccc}
\hline Parameter & Alogliptin & Pioglitazone \\
\hline LOD & $2.91 \mu \mathrm{g} / \mathrm{ml}$ & $2.96 \mu \mathrm{g} / \mathrm{ml}$ \\
LOQ & $10.4 \mu \mathrm{g} / \mathrm{ml}$ & $10.09 \mu \mathrm{g} / \mathrm{ml}$ \\
\hline
\end{tabular}

methods were stable in thermal and photolytic conditions only. The data are shown in Table 10.

\section{DISCUSSION}

Present developed RP-UPLC method showed better results when compared to the reported RP-HPLC method by (Vasanthi et al., 2017). In the reported method, where $\mathrm{C}_{18}$ column $(250 \times 4.6 \mathrm{~mm}, 5 \mu \mathrm{m})$ was used, then slow elution of solutes at
Table 8. Robustness results for change in flow rate.

\begin{tabular}{ccccccc}
\hline \multirow{2}{*}{ S. no } & $\begin{array}{c}\text { Flow Rate } \\
(\mathbf{m l} / \text { minute })\end{array}$ & \multicolumn{2}{c}{ Alogaliptin } & \multicolumn{3}{c}{ PSP } \\
\cline { 3 - 7 } & tailing & $\begin{array}{c}\text { USP } \\
\text { plate count }\end{array}$ & $\begin{array}{c}\text { USP } \\
\text { resolution }\end{array}$ & $\begin{array}{c}\text { USP } \\
\text { tailing }\end{array}$ & $\begin{array}{c}\text { USP } \\
\text { plate count }\end{array}$ \\
\hline 1 & 0.27 & 1.46 & $4,626.92$ & 3.31 & 1.29 & $6,132.29$ \\
2 & 0.3 & 1.46 & $4,725.92$ & 3.18 & 1.29 & $6,256.39$ \\
3 & 0.33 & 1.46 & $4,865.39$ & 3.02 & 1.29 & $6,352.29$ \\
\hline
\end{tabular}

*Results for actual flow ( $0.3 \mathrm{ml} /$ minute) have been considered from Assay standard.

Table 9. Robustness results for change in wavelength.

\begin{tabular}{ccccccc}
\hline \multirow{2}{*}{ S. no } & $\begin{array}{c}\text { Change } \\
\text { wavelength }\end{array}$ & \multicolumn{2}{c}{ Alogaliptin } & \multicolumn{3}{c}{ Pioglitazone } \\
\cline { 3 - 7 } & $\begin{array}{c}\text { USP } \\
\text { tailing }\end{array}$ & $\begin{array}{c}\text { USP } \\
\text { plate count }\end{array}$ & $\begin{array}{c}\text { USP } \\
\text { resolution }\end{array}$ & $\begin{array}{c}\text { USP } \\
\text { tailing }\end{array}$ & $\begin{array}{c}\text { USP } \\
\text { plate count }\end{array}$ \\
\hline 1 & $270 \mathrm{~nm}$ & 1.46 & $4,762.23$ & 3.37 & 1.29 & $6,214.27$ \\
2 & $* 280 \mathrm{~nm}$ & 1.46 & $4,725.92$ & 3.18 & 1.29 & $6,256.39$ \\
3 & $290 \mathrm{~nm}$ & 1.46 & $4,767.76$ & 2.96 & 1.29 & $6,232.23$ \\
\hline
\end{tabular}

* Results for actual wavelength 280 has been considered from accuracy standard.

Table 10. Degradation results for alogliptin and pioglitazone.

\begin{tabular}{lcccc}
\hline \multirow{2}{*}{ Sample name } & \multicolumn{2}{c}{ Alogliptin } & \multicolumn{2}{c}{ Pioglitazone } \\
\cline { 2 - 5 } & Area & \% Degraded & Area & \% Degraded \\
\hline Standard & $14,633.7$ & - & $96,256.7$ & - \\
Acid & 14,356 & 1.90 & 95,568 & 0.72 \\
Base & 13,677 & 6.54 & 94,682 & 1.64 \\
Peroxide & 13,978 & 4.48 & 93,562 & 2.80 \\
Thermal & 14,078 & 3.80 & 93,968 & 2.38 \\
Photo & 14,262 & 2.54 & 93,027 & 3.36 \\
\hline
\end{tabular}

Table 11. Stastical comparison of previous method and present method.

\begin{tabular}{lll}
\hline $\begin{array}{l}\text { Chromatographic } \\
\text { parameter }\end{array}$ & Vasanthi et al., 2017 & Ramesh et al., 2019 \\
\hline Method & RP-HPLC & RP-UPLC \\
Column & $\begin{array}{l}\text { Symmetry } \mathrm{C}_{18}(250 \times 4.6 \\
\mathrm{mm}, 5 \mu \mathrm{m})\end{array}$ & $\begin{array}{l}\text { BEH C } 18 \\
1.7 \mu)\end{array}$ \\
& $1.0 \mathrm{ml} / \mathrm{minute}$ & $0.3 \mathrm{ml} / \mathrm{minutes}$ \\
Flow rate & $20.0 \mu \mathrm{l}$ & $2 \mu \mathrm{mm}$ \\
Injection volume & Alogliptin: 2.234 minutes & Alogliptin: 0.403 minutes \\
Retention time & Pioglitazone: 3.294 minutes & Pioglitazone: 0.529 minutes \\
& 3.56 & 6.95 \\
\hline
\end{tabular}

2.234 minutes (alogliptin) and 3.294 minutes (pioglitazone) was observed, in newly developed RP-UPLC method the $\mathrm{BEH} \mathrm{C}_{18}$ column $(2.1 \times 50 \mathrm{~mm}, 1.7 \mu)$ was employed, the solutes are eluted rapidly and showed retention time at 0.403 minutes (alogliptin) and 0.529 minutes (pioglitazone), retention time difference between the two methods was noted of 2 minutes. In RP-UPLC method, mobile was prepared by ecofriendly chemicals such as $45 \%$ of phosphate buffer $(3.0 \mathrm{pH})$ and $55 \%$ of methanol, but in the reported RP-HPLC method, the mobile phase was buffer $(\mathrm{pH} 4.0)$ and acetonitrile with the ratio of $20: 80 \%$, it contains more organic phase then compared to the present method. When compared the stability indicating studies between both methods, in RP-HPLC method, when solution was placed in acid, base, 


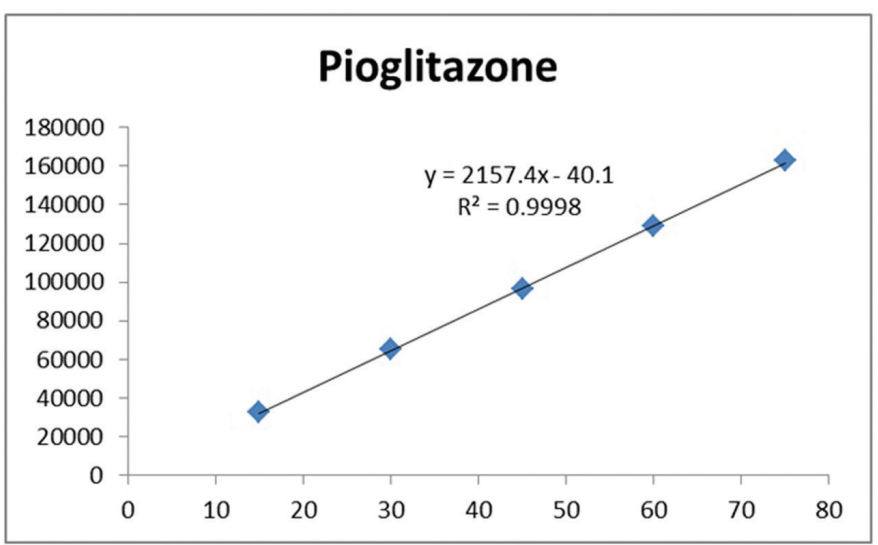

Figure 5. Linearity graph of pioglitazone.

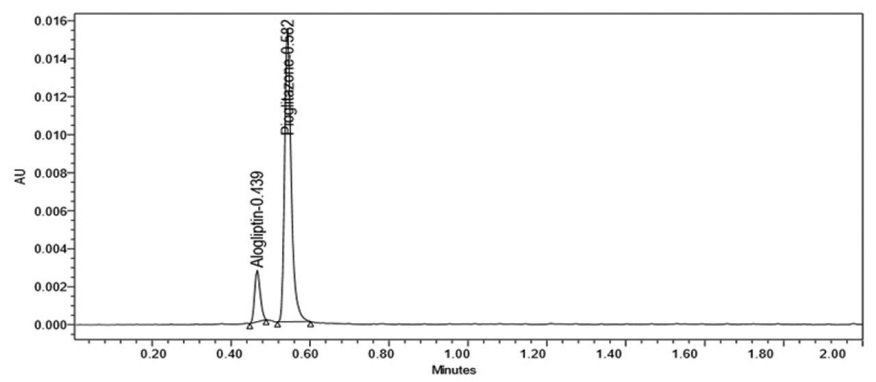

Figure 6. Less flow chromatogram of alogliptin and pioglitazone.

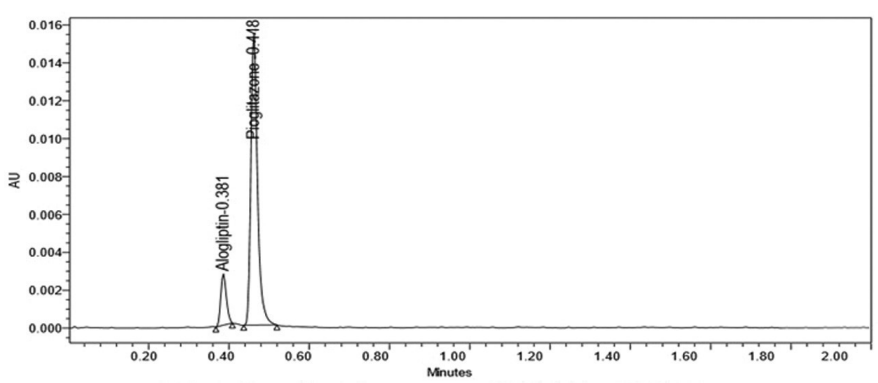

Figure 7. More flow chromatogram of alogliptin and pioglitazone.

thermal, oxidative, and photolytic stress conditions, it was stable in thermal and photolytic conditions. In acidic and basic conditions more amount of drug degraded. In the newly developed RPUPLC method, there was not much amount of drug was degraded under selected stress conditions, such as acid, base, thermal, and photolytic. It was most stable in acidic conditions. In RP-HPLC method, high amount of sample was consumed because $20 \mu \mathrm{l}$ of injection volume and flow rate was maintained at $1.0 \mathrm{ml} /$ minute. But in the current RP-UPLC method, little amount of sample was consumed because $2 \mu \mathrm{l}$ of injection volume and flow rate was maintained at $0.3 \mathrm{ml} /$ minute. The advantages of RP-UPLC method was rapid analysis, faster elution when compared to the reported RP-HPLC methods. The data are shown in Table 11.

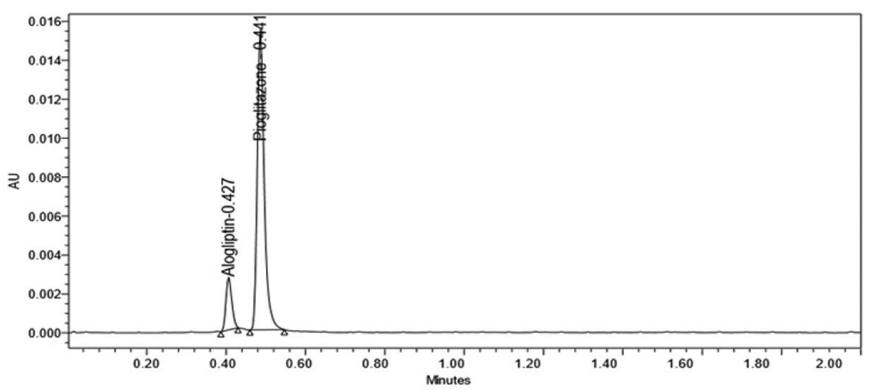

Figure 8. Less wave chromatogram of alogliptin and pioglitazone.

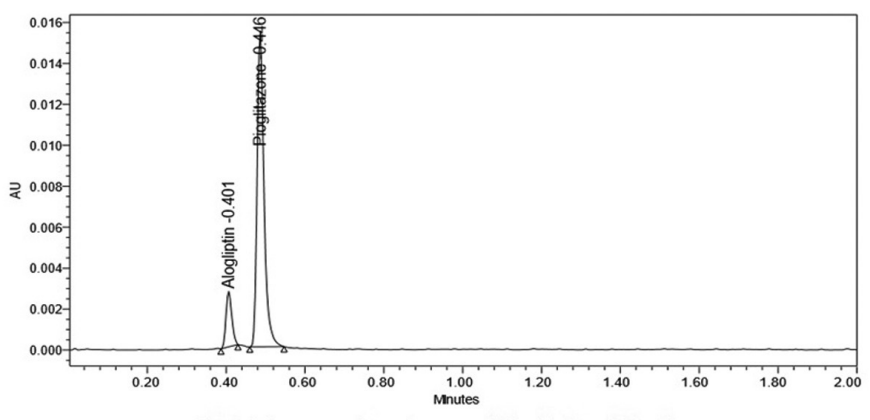

Figure 9. More wave chromatogram of alogliptin and pioglitazone.

\section{CONCLUSION}

In the present study, a new RP-UPLS method was developed for the simultaneous estimation of alogliptin and pioglitazone. The new method was validated according to the $\mathrm{ICH}$ guidelines. The method was consumed less solvents with high resolution and short run time was observed. When compared to reported RP-HPLC methods, the current RP-UPLC method was found to precise, accurate, and robust, and it can be used for the routine analysis of pharmaceutical formulations.

\section{ACKNOWLEDGMENT}

The authors thank M.S. Ramaiah University of Applied Sciences, MSR Nagar, Bangalore for their support.

\section{FINANCIAL SUPPORT AND SPONSORSHIP}

None.

\section{CONFLICT OF INTEREST}

All the authors declared that they have no conflict of interest.

\section{REFERENCES}

Al-Majed A, Bakheit AH, Abdel Aziz HA, Alharbi H, Al-Jenoobi FI, Pioglitazone. Profiles Drug Subst Excip Relat Methodol, 2016; 41:379-438.

Brunetti L, Kalabalık J. Management of type-2 diabetes mellitus in adults. Focus on individualizing non-insulin therapies. P \& T, 2012; 37:687-96.

Cabrera A, Jarvis CI, Charron D. Alogliptin: a new dipeptidyl peptidase-4 inhibitor for type 2 diabetes mellitus. Ann Pharmacother, 2013; 47:1532-9. 
Cyrus VD, Vijay S, Pioglitazone in the treatment of type 2 diabetes: safety and efficacy review. Clin Med Insights Endocrinol Diabetes, 2010; 3:43-51.

Haribabu B, Rama Krishna Veni P, BalaMurali Krishna K, Lakshmi Prameela K. Determination of alogliptin benzoate and pioglitazone simultaneously in tablet dosage forms by RP-HPLC. Marmara Pharm J, $2017 ; 21: 345-54$

ICH Q2(R1). International Conference on Harmonization, validation of analytical procedure, text and methodology. IFMA, Geneva, Switzerland, 2005.

Komal S, Amrita P, Development and validation of HPTLC method for simultaneous estimation of alogliptin benzoate and pioglitazone hydrochloride in bulk drugs and combined dosage forms, Int J Pharma Res Rev, 2015; 4:35-42.

Lincoff AM, Wolski K, Nicholls SJ, Nissen SE. Pioglitazone and risk of cardiovascular events in patients with type 2 diabetes mellitus: a meta-analysis of randomized trials. JAMA, 2007; 298:1180-8.

Marino AB, Cole SW. Alogliptin: safety, efficacy and clinical implications, J Pharm Pract, 2015; 28:99-106.

Manzoor A, Anusha M, Satishkumar SA, Kuppast IJ, Siddalingaswamy MS, Ravi MC, RP-HPLC method development and validation for simultaneous estimation of alogliptin and pioglitazone in combined tablet dosage form, World J Pharm Pharm Sci. 2015; 4:863-74.

Mokhtar MM, Sherin FH, Fotouh RM, Mona MA. Development and validation of a reversed phase HPLC method for simultaneous determination of antidiabetic drugs alogliptin benzoate and pioglitazone HCl. Der Pharmacia Sinica, 2016; 7:32-40.
Neelima B, Kumar PR, Bindu VH, Prasad YR. A validated stability indicating RP-HPLC method for simultaneous determination of alogliptine and pioglitazone in bulk and pharmaceutical formulations. In J Pharm, 2014; 4:458-64.

Raval K, Srinivasa U. Development and validation of HPLC method for the simultaneous estimation of pioglitazone and alogliptin in bulk and dosage form. Int J Curr Res, 2014; 6:10201-7.

Vasanthi R, Noori K, Shyam Sundar P, Alagar Raja M, Dutt R. Development of rapid stability indicating method for simultaneous estimation of alogliptin and pioglitazone in bulk and combined dosage form by RP-HPLC method, Indo Am J Pharm, 2017; 3(5):234-44.

\section{How to cite this article:}

Dhani R, Guptha HKDR, Rajamanickam D. Development of stability indicating method for the simultaneous estimation of alogliptin and pioglitazone in bulk and tablet dosage form by reversed-phase ultra-performance liquid chromatography method. J Appl Pharm Sci, 2019; 9(12):051-056. 